\title{
Implikasi Sesar Kendeng terhadap Bahaya Gempa dan Pemodelan Percepatan Tanah di Permukaan di Wilayah Surabaya
}

\author{
Vidya Amalia Harnindra ${ }^{1}$, Bambang Sunardi ${ }^{2}$, dan Bagus Jaya Santosa ${ }^{1}$ \\ ${ }^{1}$ Departemen Fisika, Fakultas Matematika dan Ilmu Pengetahuan Alam, Institut Teknologi Sepuluh Nopember \\ (ITS) \\ ${ }^{2}$ Badan Meteorologi Klimatologi dan Geofisika Jakarta Pusat \\ e-mail: bjs@physics.its.ac.id
}

\begin{abstract}
Abstrak-Kota Surabaya merupakan ibukota propinsi Jawa Timur Berdasarkan data Badan Pusat Statistik, Surabaya dapat dikategorikan sebagai kota yang cukup padat. Salah satu bahaya gempa di wilayah Surabaya berasal dari sesar Kendeng yang terbukti aktif dengan pergerakan 5 milimeter per tahun. Implikasi sesar kendeng terhadap bahaya gempa di wilayah Surabaya dapat dilakukan salah satunya dengan metode Deterministic Seismic Hazard Analisis (DSHA). Perhitungan bahaya gempa dengan metode DSHA dilakukan menggunakan modifikasi software CRISIS 2007 yang akan menghasilkan percepatan tanah di batuan dasar. Hasil dari DSHA selanjutnya dipergunakan untuk memodelkan percepatan tanah di permukaan pada lokasi (site) yang ditinjau di wilayah Surabaya dengan menggunakan software Nonlinear Earthquake site Response Analyses (NERA). Nilai percepatan tanah di batuan dasar untuk wilayah Surabaya dengan memperhitungkan keberadaan sesar Kendeng memiliki nilai berkisar antara $0.26 \mathrm{~g}$ 0.71g. Model percepatan tanah di permukaan untuk lokasi yang ditinjau pada koordinat $112,7483^{\circ}$ BT dan $7,289^{\circ}$ LS memiliki nilai maksimum sekitar $0.34 \mathrm{~g}$.
\end{abstract}

Kata Kunci-DSHA, Percepatan Tanah, Sesar Kendeng.

\section{PENDAHULUAN}

$\mathrm{S}$ EBAGAI kota terbesar kedua setelah Jakarta, Surabaya merupakan tempat yang potensial bagi investor. Dengan demikian pembangunan struktur dan infrastruktur seharusnya memperhatikan aspek kegempaan untuk menghindari kerugian akibat gempa. Salah satu upaya pengurangan resiko bencana gempa bumi pada suatu daerah adalah dengan menggali dan menganalisis seluruh potensi bahaya gempa bumi secara lengkap. Dapat dilakukan usaha berupa perencanaan dan pembangunan bangunan yang tahan gempa untuk mengurangi resiko yang ditimbulkan akibat gempa bumi.

Penelitian terbaru yang dipublikasikan di Geophysical Research Letter mengungkap bahwa sesar Kendeng bergerak aktif dengan pergerakan 5 milimeter per tahun dan menjadi sumber gempa di wilayah Jawa Timur. Sesar Kendeng melintang sejauh kurang lebih 300 kilometer dari selatan Semarang, Jawa Tengah, hingga Jawa Timur (sains.kompas.com, 2016). Implikasi sesar kendeng terhadap bahaya gempa di Kota Surabaya dapat dilakukan dengan analisis bahaya gempa (seismic hazard). Salah satu metode yang dapat dipergunakan dalam analisis bahaya gempa adalah metode Deterministic Seismic Hazard Analisis (DSHA).
Perhitungan bahaya gempa menggunakan metode DSHA dapat menghasilkan peta bahaya gempa yang tercermin dalam peta percepatan tanah. Data percepatan tanah memegang peranan penting untuk analisis dinamis tanah. Hasil dari DSHA selanjutnya dapat dipergunakan untuk memodelkan percepatan tanah di permukaan pada lokasi (site) yang ditinjau di Kota Surabaya. Percepatan tanah merupakan salah satu komponen utama dalam penyusunan peraturan kegempaan. Tujuan dari penelitian ini adalah untuk menentukan percepatan tanah di batuan dasar untuk wilayah Surabaya dengan memperhitungkan keberadaan sesar Kendeng dan memodelkan percepatan tanah di permukaan di lokasi yang ditinjau di wilayah Surabaya.

Gempa bumi ialah sebuah guncangan hebat yang menjalar ke permukaan bumi akibat pelepasan energi di dalam bumi secara tiba-tiba yang ditandai dengan patahnya lapisan batuan pada kerak bumi. Gempa bumi merupakan fenomena alam yang tidak terduga kehadirannya [1]. Akumulasi energi penyebab terjadinya gempa bumi dihasilkan dari pergerakan lempeng-lempeng tektonik. Energi yang dihasilkan dan dipancarkan ke segala arah berupa gelombang gempa bumi sehingga efeknya dapat dirasakan sampai ke permukaan bumi. Mekanisme gempa bumi dapat dijelaskan dengan pendekatan teori seperti dalam teori lempeng tektonik. Terdapat dua teori yang menyatakan proses terjadinya atau asal mula gempa yaitu pergeseran sesar dan teori kekenyalan elastis. Gerakan secara tiba-tiba sepanjang sesar merupakan penyebab yang sering terjadi [2].

Wilayah kota Surabaya merupakan daerah yang rata-rata ialah berupa dataran rendah, yang berkisar $80 \%$ merupakan endapan alluvial dan sisanya merupakan perbukitan rendah yang dibentuk oleh tanah hasil dari pelapukan batuan tersier. Dataran rendah terbentuk dari endapan alluvial sungai dan endapan pantai. Dataran rendah meliputi wilayah Surabaya Timur, Utara dan Selatan. Bagian tengah Kota Surabaya terbentuk oleh endapan Sungai Brantas beserta cabang-cabang sungainya dan endapan Sungai Rowo. Endapan Sungai Brantas berasal dari letusan gunung-gunung berapi yang berada di hulu dan beberapa rombakan sebelumnya [3].

Secara geologi, kota Surabaya terbentuk oleh batuan sedimen yang berumur Miosen sampai Plistosen. Batuan sedimennya adalah bagian dari lajur Kendeng dengan formasi Sonde, Lidah, Pucangan, dan formasi Kabuh. Batuan dasar 
untuk kota Surabaya merupakan formasi Lidah yang berumur Pliosen. Formasi ini berada pada kedalaman 250 - 300 meter. Selain itu derah Surabaya berupa cekungan endapan aluvial muda hasil endapan laut dan sungai, tuf dan batu pasir [4].

Fungsi atenuasi telah banyak berkembang dalam kurun waktu dua dekade terakhir. Hal ini dipicu oleh tersedianya data-data strong motion dari kejadian-kejadian gempa yang terjadi. Pada analisa bahaya kegempaan biasanya dapat dengan cara deterministik dan dengan cara probabilistik. Analisis bahaya gempa memerlukan nilai percepatan tanah akibat gempa. Pada analisis resiko gempa apabila lokasi yang ditinjau tidak mempunyai data rekaman gempa, maka untuk memperkirakan besarnya percepatan maksimum tanah digunakan fungsi atenuasi (Campbell, 2008). Pada penelitian ini menggunakan fungsi atenuasi Abragamson dan Silva (1997) dan Sea99 (1999).

Abrahamson dan Silva mengembangkan atenuasi PGA menjadi atenuasi PSA yang berdasar pada data gempa dan parameter-parameter tertentu. Data gempa yang dipakai semuanya termasuk gempa dangkal (shallow crustal earthquakes). Atenuasi Abrahanson dan Silva (1997) selanjutnya disingkat menjadi atenuasi A-S (1997). Setelah mengalami proses regresi secara bertahap maka rumusan atenuasi A-S dinyatakan dalam:

Ln Sa(g) $=\mathrm{f}_{1}\left(\mathrm{M}, \mathrm{R}_{\text {rup }}\right)+\mathrm{Ff}_{3}(\mathrm{M})+\mathrm{HWf}_{4}\left(\mathrm{M}, \mathrm{R}_{\text {rup }}\right)+\mathrm{Sf}_{5}\left(\mathrm{pga}_{\text {rock }}\right)$

dimana, $\mathrm{Sa}(\mathrm{g})$ ialah spektra percepatan dalam $(\mathrm{g}), \mathrm{R}_{\text {rup }}$ ialah jarak terdekat ke bidang rupture $(\mathrm{km}), \mathrm{M}$ ialah magnitude momen, $\mathrm{F}$ ialah suatu koefisien untuk menandai style of faulting yang dipakai ( $\mathrm{F}=1$ untuk reverse, $\mathrm{F}=0,5$ untuk oblique dan $\mathrm{F}=0$ untuk tipe fault yang lain), $\mathrm{HW}$ adalah suatu dummy variable $(\mathrm{HW}=1$ untuk site di hinging wall dan $\mathrm{HW}=0$ untuk site di footing wall) untuk memperhitungkan pengaruh parameter hinging wall ataupun footing wall, dan $\mathrm{S}$ ialah variable dummy untuk kelas site (nilai $\mathrm{S}=0$ untuk rock dan tanah dangkal dan $\mathrm{Ss}=1$ untuk tanah daalam) [5].

Pada atenuasi SEA99 dikembangkan persamaan prediksi percepatan tanah puncak horizontal dan pseudo respon spektra wilayah ekstensional dengan redaman 5\% [5]. Persamaan ini dapat digunakan untuk sumber dengan besaran magnitude antara 5.0-7.7 moment magnitude dan dengan rentang jarak ekstensional 0-100 km. persamaan atenuasi SEA99 dapat dinyatakan dalam

$\log _{10} \mathrm{Y}=\mathrm{b}_{1}+\mathrm{b}_{2}(\mathrm{M}-6)+\mathrm{b}_{3}(\mathrm{M}-6)^{2}+\mathrm{b}_{5} \log _{10} \mathrm{R}+\mathrm{b}_{6} \Gamma$

dimana, Y merupakan percepatan puncak horizontal dalam (g), $M$ ialah magnitudo momen, $\Gamma=0$ untuk batuan dan 1 untuk tanah. Dengan nilai $R$ dapat dihitung dengan

$$
R=\sqrt{R_{j b}^{2}+h^{2}}
$$

$\mathrm{R}_{\mathrm{jb}}$ merupakan jarak Joyner-Boore dan $\mathrm{h}$ merupakan koefisien regresi yang bergantung pada periode [6].

Analisa seismic hazard secara deterministic mengacu pada sejarah gempa dan kondisi geologi untuk mengidentifikasikan sumber-sumber gempa dan untuk mengetahui sumber gempa terkuat yang mampu dihasilkan tanpa memperhatikan waktu, karena gempa bumi dapat terjadi kapan saja. DSHA membutuhkan determinasi dari besar gempa maksimum atau kemungkinan terbesar gempa bumi yang menyebabkan akibat terburuk [7]. Hal ini kemudian dapat dikembangkan untuk menentukan Maximum Credible Earthquakes (MCEs) untuk mengetahui gempa yang paling besar yang mungkin terjadi. MCEs adalah sebuah gempa yang diperkirakan akan terjadi sekali dalam 2500 tahun, yang berarti peluang gempa terjadi sekitar 2\% terjadi dalam 50 tahun.

Pada metode deterministic seismic hazard analysis, memiliki prosedur seperti pada gambar dibawah. Digambarkan dengan empat tahap, DSHA memiliki tahap-tahap yang sangat sedehana. Pada tahapan DHSA, ketika memasukkan sumber yang digunakan maka akan didapatkan respon dari sumber tersebut. DSHA memberikan estimasi kedepan untuk evaluasi dari percepatan tanah atau guncangan yang paling buruk. Namun, tidak menyediakan mengenai informasi kemungkinan terjadinya gempa pengendali. Kemungkinan tingkat gemetar yang bisa didapatkan ialah dalam jangka waktu yang terbatas, atau efek dari ketidakpastian dalam berbagai langkah yang diperlukan untuk menghitung dapat dihasilkan karakteristik percepatan tanah. Hal yang paling penting pada metode DSHA ialah keputusan para ahli untuk menentukan sumber yang digunakan dalam analisis bahaya ini [8].
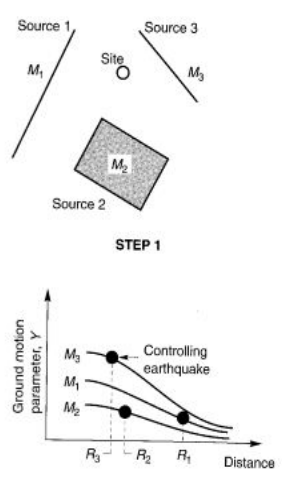

STEP 3

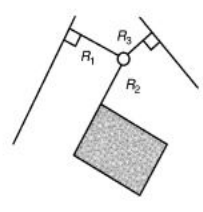

STEP 2

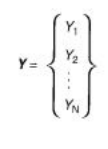

STEP 4
Gambar 1. Empat tahapan deterministic seismic hazard analysis.

Gempa bumi dapat didefinisikan sebagai sumber beban dinamis. Data yang dibutuhkan untuk analisa dinamis akibat beban gempa adalah data riwayat waktu percepatan gempa. Pada kenyataannya data catatan gempa yang ada di Indonesia lebih banyak dalam bentuk informasi mengenai lokasi pusat gempa, magnitude, kedalaman dan mekanismenya sedangkan data dalam bentuk riwayat waktu masih sangat kurang. Hal ini disebabkan jumlah stasiun pencatat gempa di Indonesia yang masih sangat sedikit bila dibandingkan luas wilayah Indonesia. Untuk mengatasi hal tersebut digunakanlah beberapa metode alternatif antara lain, menggunakan data riwayat waktu percepatan dari daerah yang memiliki kondisi geologi dan seismologi yang mendekati lokasi kajian. Yang kedua ialah menggunakan riwayat waktu percepatan dari lokasi lain yang kemudian diskalakan sesuai dengan target parameter pergerakan batuan dasar (percepatan maksimum dan periode). Dan yang terakhir ialah dengan membuat riwayat waktu percepatan sintetik yang disesuaikan dengan kondisi geologi dan seismologi lokasi kajian. 
Respon spekta adalah suatu spektra yang disajikan dalam bentuk grafik atau plot antara reaksi maksimum dari sistem satu derajat kebebasan terhadap suatu beban dinamis sebagai fungsi dari frekuensi alami dan damping rasio dari sistem tersebut. Respon spektra merupakan suatu alternative single parameter lain yang dapat dipaai untuk menyatakan daya rusak gempa terhadapat struktur [9].

Semakin besar nilai percepatan tanah, akan semakin besar juga nilai maksimum spectral acceleration (SA). Maka akan semakin besar kekuatan gempa dan semakin parah kerusakan yang ditimbulkannya. Untuk kebutuhan desain praktis, maka respon spektra desain dibuat dengan bentuk respon spektra yang telah dinormalisir dengan nilai percepatan maksimum di batuan dasar. Bentuk respon spektra di desain lebih sederhana agar lebih mudah dipakai dalam menentukan faktor beban gempa [10].

\section{METODE PENELITIAN}

\section{A. Data Gempa}

Data yang digunakan dalam penelitian ini ialah data gempa di sekitar patahan kendeng dari bulan Januari tahun 1900 sampai bulan Desember 2016 dengan batas kedalaman maksimum $50 \mathrm{~km}$. Data tersebut dapat dikumpulkan dari lembaga yang melakukan pengamatan kegempaan baik nasional maupun internasional antara lain katalog gempa Badan Meteorologi Klimatologi dan Geofisika (BMKG) dan katalog gempa National Earthquake Information Center U.S. Geological Survey (NEIC-USGS).

\section{B. Data Standart Penetration Test (SPT)}

Pada penelitian ini, diperlukan data Standart Penetration Test (SPT) yang digunakan untuk analisis dinamika tanah di lokasi tinjauan. Data SPT yang digunakan ialah pada lokasi tinjauan di Jalan Flores, Kecamatan Wonokromo, Kota Surabaya yaitu pada koordinat 112,74830 BT dan 7,2890 LS.

\section{Data Inisial Percepatan Tanah}

Untuk tahap spectral matching diperlukan data inisial percepatan tanah yang dapat diperoleh dari PEER data strong motion database.

\section{Pengolahan Data}

Alur penelitian Implikasi Sesar Kendeng Terhadap Bahaya Gempa dan Pemodelan Percepatan Tanah di Wilayah Surabaya dapat diuraikan pada flowchart pada Gambar 2.

\section{HASIL DAN PEMBAHASAN}

\section{A. Analisa Deterministic Seismic Hazard}

Hasil analisis deterministic seismic hazard ialah berupa nilai Peak Ground Acceleration (PGA) dan spektra percepatan di batuan dasar. Untuk mendapatkan nilai PGA dibatuan dasar digunakan dua fungsi atenuasi yaitu Abrahamson \& Silva (1997) dan SEA99 (1997). Percepatan tanah maksimum (PGA) di batuan dasar diperoleh melalui pemodelan sumber gempa. Sumber gempa yang digunakan ialah sumber gempa shallow crustal yaitu sesar Kendeng. Hasil perhitungan PGA di batuan dasar dengan menggunakan fungsi atenuasi Abrahamson \& Silva (1997) menunjukkan rentang nilai percepatan antara $0.26 \mathrm{~g}-0.71 \mathrm{~g}$, sedangkan hasil perhitungan PGA di batuan dasar dengan menggunakan fungsi atenuasi SEA99 (1997) menunjukkan rentang nilai percepatan antara $0.12 \mathrm{~g}-0.3 \mathrm{~g}$. Dari hasil yang didapatkan dapat dilihat bahwa nilai PGA akibat sumber gempa relatif lebih tinggi di daerah Surabaya Selatan.

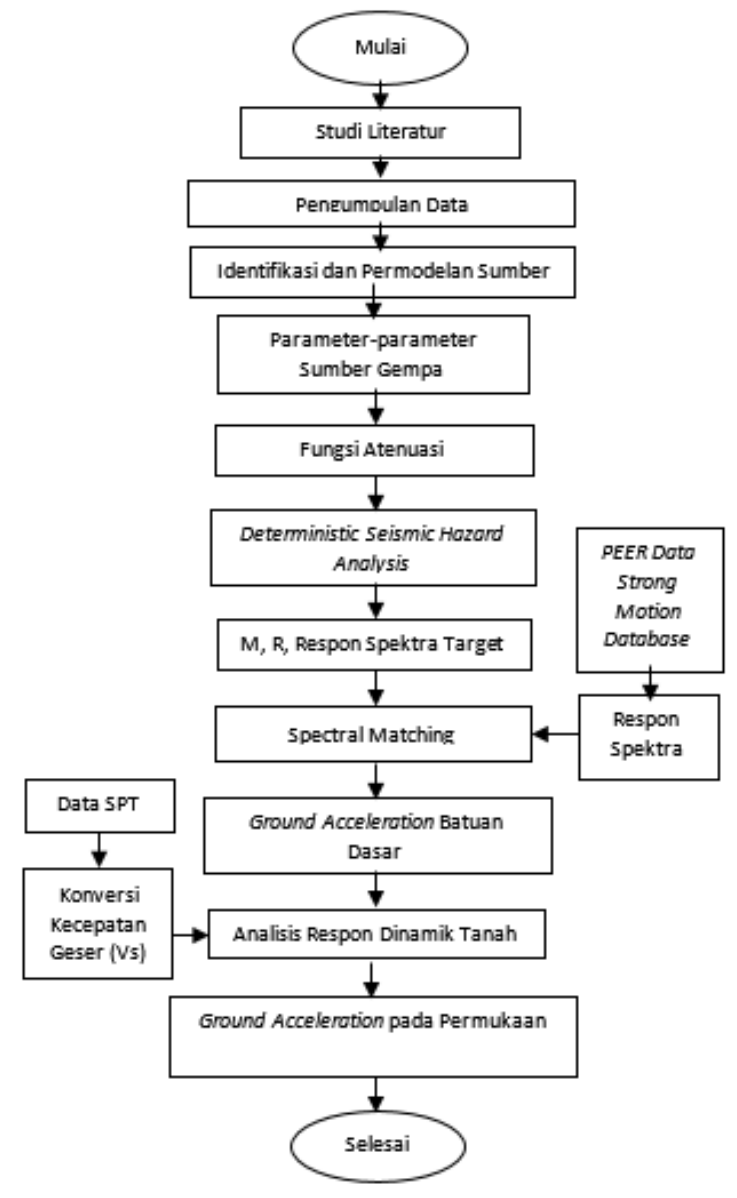

Gambar 2. Diagram alir penelitian.

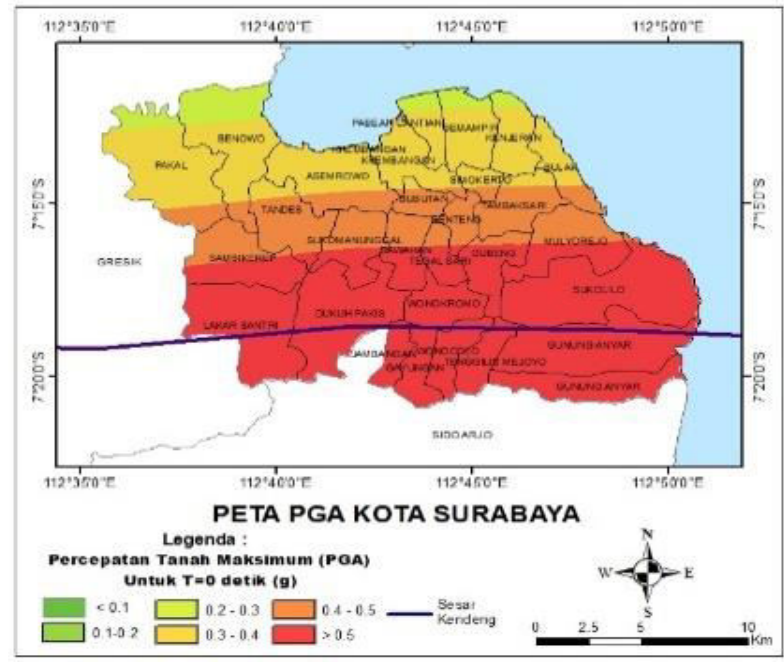

Gambar 3. Peta PGA Kota Surabaya menggunakan atenuasi Abrahamson \& Silva (1997). 


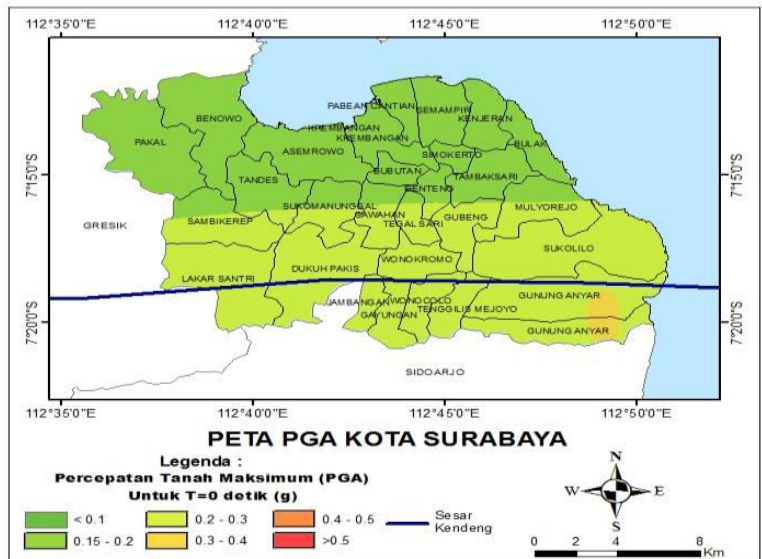

Gambar 4. Peta PGA Kota Surabaya menggunakan atenuasi SEA99 (1997).

Hasil perhitungan PGA di batuan dasar yang digunakan untuk tahapan selanjutnya ialah perhitungan menggunakan fungsi atenuasi Abrahamson \& Silva (1997) dikarenakan penelitian ini menggunakan metode deterministik yang merupakan metode dengan mengunakan skenario terburuk yang mungkin terjadi.

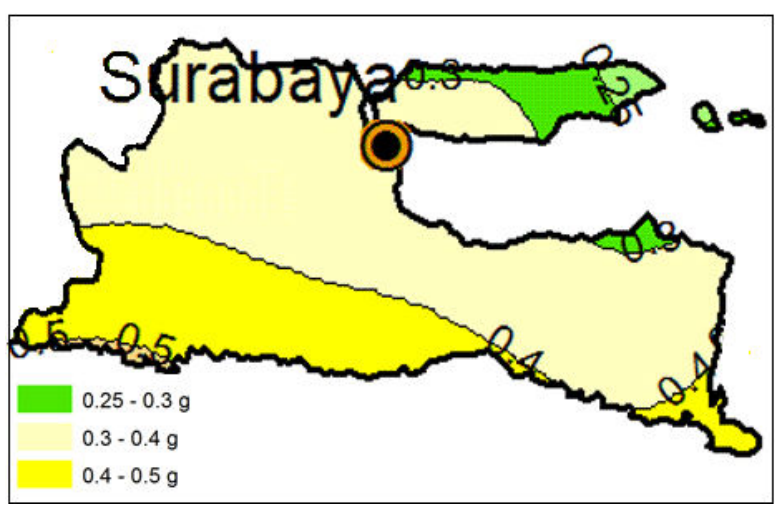

Gambar 5. Peta percepatan tanah maksimum (PGA) di batuan dasar (SNI 1726:2012).

Hasil deterministic seismic hazard yang diakibatkan oleh adanya sesar kendeng apabila dibandingkan dengan peta hazard gempa bumi di dalam SNI 1726:2012 diperlihatkan pada Gambar 4.3. Peta hazard gempa dalam SNI 1726:2012 belum memasukkan keberadaan sesar Kendeng dalam perhitungannya. Nilai PGA untuk Kota Surabaya di dalam SNI 1726:2012 berkisar antara $0.3 \mathrm{~g}-0.4$. Nilai PGA yang didapatkan dengan memasukkan sumber gempa sesar Kendeng memiliki nilai lebih relatif lebih tinggi jika dibandingkan dengan nilai PGA yang tidak melibatkan sesar Kendeng. Hal tersebut dikarenakan sumber gempa sesar Kendeng melewati kota Surabaya.

Penelitian khusus juga dilakukan pada lokasi tinjauan yang berada di Jalan Flores, Kecamatan Wonokromo, Kota Surabaya (koordinat 7,289 LS dan 112,7483 BT). Dari analisis deterministic seismic hazard ini diperoleh juga magnitude (M) dan jarak (R) dominan yang berpengaruh pada lokasi tinjuan, yaitu magnitude (M) dominan $7(\mathrm{Mw})$ dan $\mathrm{R}$ dominan $12 \mathrm{Km}$. Di lokasi tinjuan selanjutnya ditentukan target spectra yang merupakan respon spektra berada di batuan dasar yang akan menjadi acuan untuk mendapatkan ground acceleration sintetik yang sesuai untuk lokasi tinjauan. Ground Acceleration gempa yang dipilih selanjutnya dimodifikasi sehingga spektranya mendekati respon spektra target yang dikehendaki melalui analisis spectral matching.

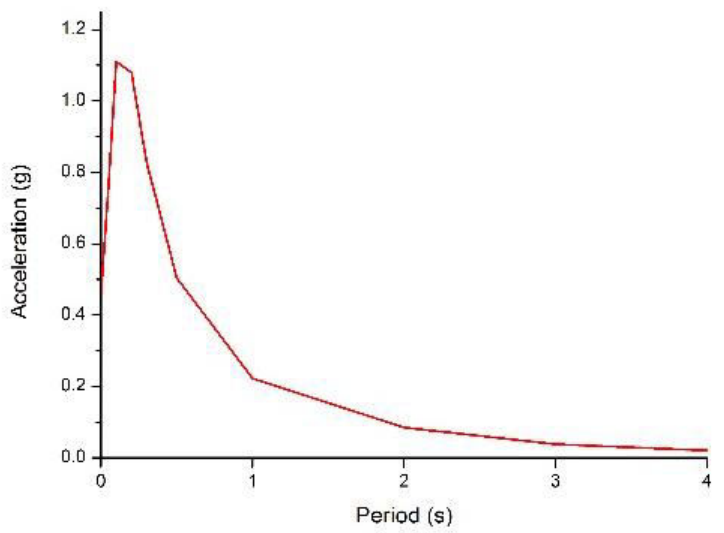

Gambar 6. Kurva target spektra terskalakan untuk site yang digunakan.

\section{B. Initial Ground Motion}

Analisis deterministic seismic hazard memberikan gambaran gempa penentu pada lokasi tinjauan. Dikarenakan belum tersedianya rekaman gempa dengan magnitude dan jarak yang sama dengan gempa penentu, maka dicari rekaman percepatan tanah yang memiliki karakteristik yang sesuai dengan karakteristik tersebut, baik magnitude, jarak maupun mekanismenya untuk dijadikan sebagai initial ground motion pada lokasi yang ditinjau. Initial ground motion yang dipilih pada penelitian ini ialah ground acceleration gempa Iwate, di Jepang tahun 2008.

Dengan Initial Ground Motion yang digunakan memiliki magnitude 6.9 $\mathrm{Mw}$ dan jarak 12,83 Km. Besarnya $\mathrm{M}$ dan $\mathrm{R}$ gempa Iwate, Jepang 2008 tidak sama persis dengan hasil analisis deterministic seismic hazard, namun memiliki nilai yang cukup mendekati dengan magnitude (M) dan jarak (R) dari hasil tersebut. Gambar 4.5 menunjukkan initial ground motion dari rekaman gempa Iwate, Jepang 2008. Percepatan tanah pada gambar 4.5 merupakan percepatan tanah di batuan dasar, dengan nilai percepatan tanah maksimum (PGA) sebesar $0.247 \mathrm{~g}$.

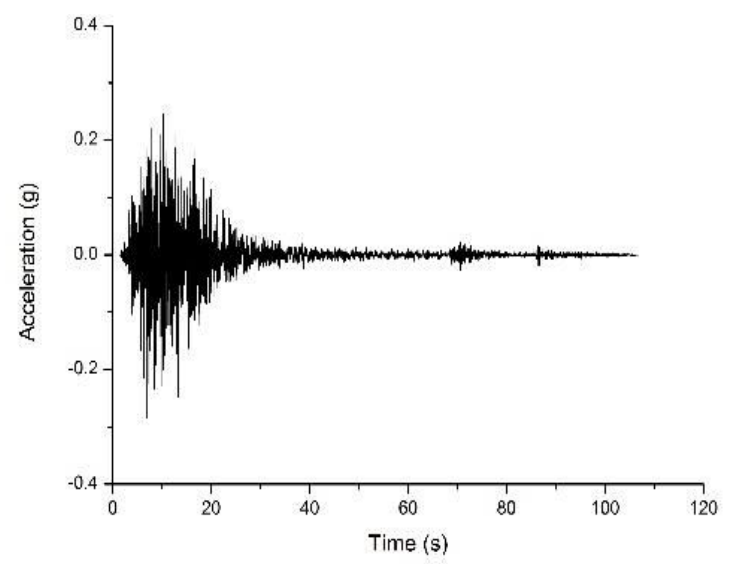

Gambar 6. Rekaman gempa Iwate, Japan 2008 sebagai initial ground motion. 


\section{Analisa Spectral Matching}

Berdasarkan hasil analisis deterministic seismic hazard untuk lokasi yang ditinjau data initial ground motion gempa Iwate, Jepang 2008 dengan magnitude 6.9 dan jarak $12.83 \mathrm{~km}$ direkomendasikan untuk diskalakan atau dilakukan analisis spectral matching guna merepresentasikan sumber gempa shallow crustal (sesar kendeng). Gambar 4.6 menunjukkan hasil analisis spectral matching di lokasi yang ditinjau. Nampak hasil analisis spectral matching (warna hijau) hampir mendekati dengan respon spektra target yang diharapkan (warna merah).

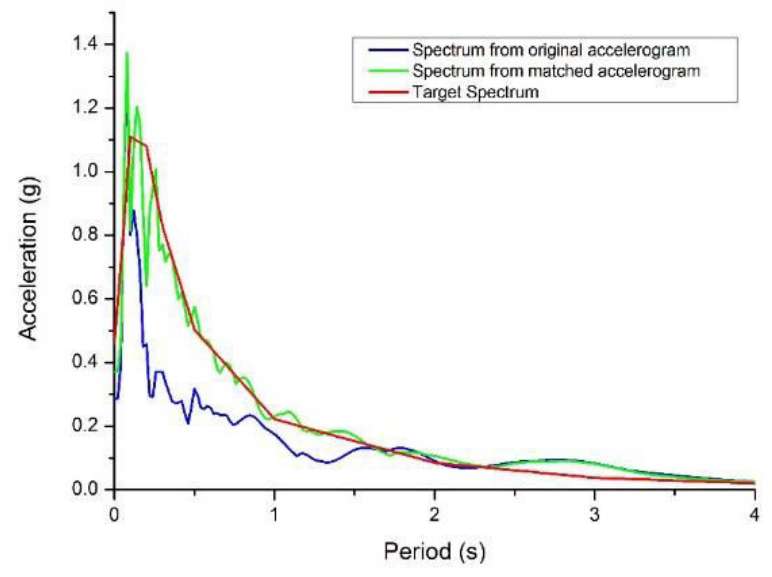

Gambar 7. Hasil analisis spectral matching pada lokasi yang ditinjau.

Time series percepatan dari hasil spectral matching disesuaikan dan disekalakan dengan target spektra yang telah ditentukan sebelumnya, maka dari itu time series percepatan dari hasil spectral matching memiliki perubahan dibandingkan dengan time series pada initial ground motion.

\section{Ground Acceleration di Batuan Dasar}

Untuk mendapatkan hasil analisa kegempaan yang akurat, ground acceleration di batuan dasar ini dibuat dengan memperhitungkan kondisi tektonik, analisis hazard gempa, dan respon spektra target. Ground acceleration di batuan dasar dapat memberikan gambaran spesifik menganai kondisi geologi dan parameter kegempaan antara lain maksimum percepatan gempa di batuan dasar, durasi, serta frekuensi. Gambar 4.7 berikut membahas ground acceleration di batuan dasar untuk lokasi yang ditinjau. Nilai maksimum percepatan tanah di batuan dasar pada lokasi yang ditinjau ialah $0.52 \mathrm{~g}$.

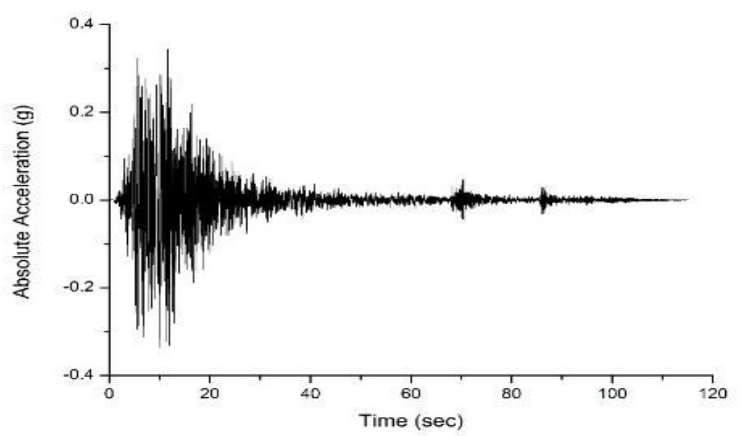

Gambar 8. Percepatan tanah sintesis di batuan dasar hasil matching pada lokasi yang ditinjau.

\section{E. Analisa Respon Dinamika Tanah}

Analisis respon dinamika tanah dipergunakan untuk mendapatkan time series percepatan tanah dan respon spektra di permukaan tanah pada lokasi tinjauan. Analisis respon dinamika tanah memerlukan parameter dinamik tanah yang didapatkan dari pengujian tanah atau Standart Penetration Test (SPT) pada lokasi yang ditinjau. Perambatan gelombang dari batuan dasar ke permukaan tanah dilakukan dengan bantuan software NERA dan didapatkan hasil yaitu ground acceleration di permukaan tanah, faktor amplifikasi dan respon spektra di permukaan tanah.

Dengan software NERA, nilai kecepatan gelombang geser (Vs) yang diinputkan akan diperoleh nilai modulus geser $\left(\mathrm{G}_{\max }\right)$. Dari gambar 4.8 dapat dilihat pada grafik bahwa nilai kecepatan gelombang geser cenderung meningkat seiring peningkatan kedalaman sehingga menyebabkan nilai kecepatan gelombang geser yang semakin besar. Nilai kecepatan gelombang geser pada kedalaman $2 \mathrm{~m}$ mencapai 179.752 $\mathrm{m} /$ detik, sedangkan pada kedalaman 14 m mencapai 242.573 $\mathrm{m} /$ detik dan pada kedalman $26 \mathrm{~m}$ mencapai $260.946 \mathrm{~m} /$ detik. Data tersebut juga disajikan dalam grafik pada Gambar 4.8.

Respon dinamik tanah dapat digambarkan sebagai perambatan gelombang dari batuan dasar ke permukaan tanah. Hasil dari perambatan gelombang 1D dari batuan dasar ke permukaan pada site yang ditinjau dapat dilihat pada Gambar 4.9. Nilai percepatan tanah di permukaan pada site yang ditinjau ialah sebesar $0.34 \mathrm{~g}$.

Hasil lain dari analisis respon dinamika tanah adalah respon spektra percepatan di permukaan tanah pada lokasi yang ditinjau sebagaimana ditunjukkan pada gambar 4.10. Respon spektra merupakan suatu altenatif parameter lain yang dapat dipakai untuk menyatakan daya rusak gempa terhadap struktur. Respon spektra percepatan untuk lokasi yang ditinjau menunjukkan nilai percepatan sebesar $0.72 \mathrm{~g}$ pada $\mathrm{T}=0.2$ detik dan $0.42 \mathrm{~g}$ pada $\mathrm{T}=1$ detik.

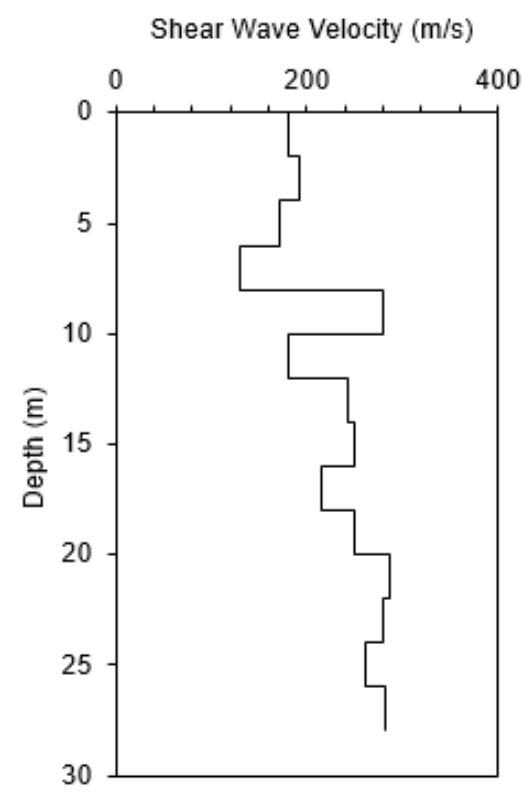

Gambar 9. Variasi Vs terhadap kedalaman pada site yang ditinjau 


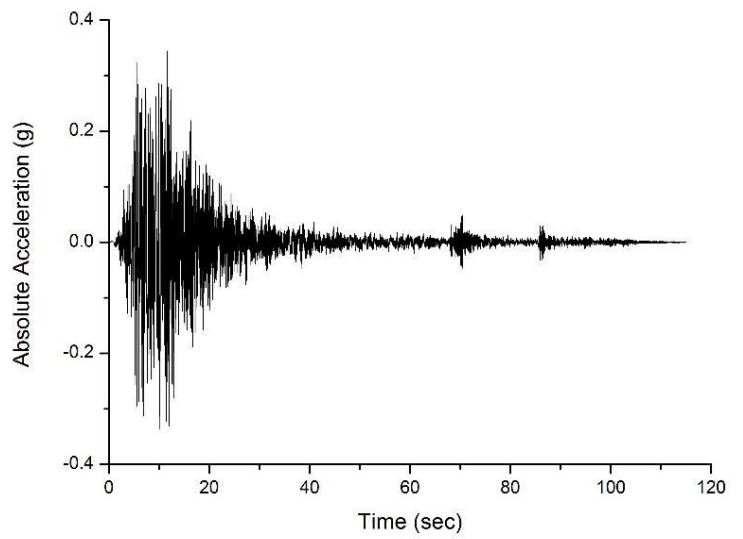

Gambar 10. Percepatan tanah sintetis di permukaan tanah pada lokasi yang ditinjau.

Percepatan maksimum dan respon spektra yang terjadi di permukaan dipengaruhi oleh kondisi tanah seperti jenis lapisan tanah dan tebal lapisan tanah. Respon spektra tidak saja dipakai pada struktur dengan derajat kebebasan tunggal tetapi juga dapat dipakai pada struktur dengan derajat kebebasan banyak atau bangunan bertingkat banyak.

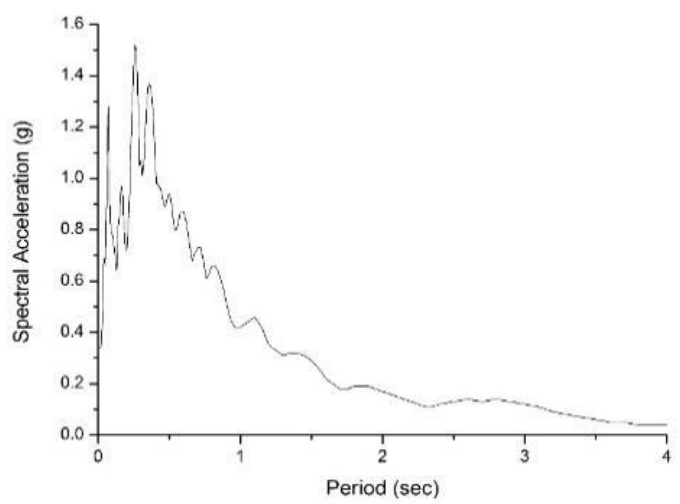

Gambar 11. Respon spektra percepatan tanah di permukaan pada lokasi yang ditinjau.

\section{KESIMPULAN DAN SARAN}

Dari hasil pengolahan data dan analisa data yang telah dilakukan pada penelitian Tugas Akhir ini, dapat diambil kesimpulan bahwa:

1. Percepatan tanah di batuan dasar untuk wilayah Surabaya dengan memperhitungkan keberadaan sesar Kendeng memiliki nilai berkisar antara $0.26 \mathrm{~g}-0.71 \mathrm{~g}$.

2. Model percepatan tanah di permukaan untuk lokasi yang ditinjau yaitu pada koordinat $112,7483^{\circ} \mathrm{BT}$ dan $7,289^{\circ}$ LS memiliki nilai maksimum sekitar $0.34 \mathrm{~g}$.

Adapun saran dari penulis yaitu penelitian dengan metode Probabilistic Seismic Hazard Analysis (PSHA) dapat dilakukan untuk melengkapi hasil DSHA sebagai upaya mitigasi bahaya gempa khususnya di wilayah Surabaya.

\section{DAFTAR PUSTAKA}

[1] I. Ramadhani and B. J. Santosa, "Relokasi Hypocentre Gempa Bumi Dengan Velest (JHD) dan Estimasi Sesar Daerah Sumatera Selatan," J. Fis. dan Apl., vol. 13, no. 2, 2017.

[2] E. R. Engdahl, R. D. Van der Hilst, and R.P. Bulard, "Global teleseismic earthquake relocation with improved travel times and procedures for depth determination," Bull. Seismol. Soc. Am., vol. 88, pp. 722-743, 1998.

[3] S. Bahri and Madlazim, "Pemetaan Topografi, Geofisika dan Geologi Kota Surabaya," J. Penelit. Fis. dan Apl., 2012.

[4] Soekardi, Geologi Lembar Pacitan, Jawa,Pusat Penelitian dan Pengembangan Geologi Indonesia. 1992.

[5] W. Prawirodikromo, Seismology Teknik dan Rekayasa Kegempaan, 1st ed. Yogyakarta: Pustaka Pelajar, 2012.

[6] P. Spudich, W. B. Joyner, A. G. Lindh, D. M. Boore, B. M. Margaris, and J. B. Fletcher, "A revised ground motion prediction relation for use in extensional tectonic regimes," Bull. Seism. Soc. Am., vol. 89, pp. 1156-1170, 1999.

[7] S. Pailopee, Y. Sugiyama, and P. Charusiri, "Deterministic and probabilistic seismic hazard analyses in Thailand and adjacent areas using active fault data," 2009.

[8] Kramer and Steven L, Geotechnical Earthquake Engineering. USA: Prentice-hall Inc, 1996.

[9] I. W. Sengara, "An Integrated Seismic Hazard Investigation for City of Bandung, Asahi Glass Foundation Research Report," Bandung, 2010.

[10]F. Aldiamar, "Analisa Resiko Gempa dan Pembuatan Respon Spektra Desain Untuk Jembatan Suramadu dengan Pemodelan Sumber Gempa 3D," Institut Teknologi Bandung, 2007. 